\title{
A rare cause of upper airway obstruction in neonates
}

\author{
Rana Alia, ${ }^{1}$ Irfan Jeeva, ${ }^{2}$ Lawrence Miall, ${ }^{3}$ Vernon Long $^{2}$ \\ 1Department of Neonatology, Leeds Teaching Hospitals NHS Trust, Leeds, UK \\ ${ }^{2}$ Department of Ophthalmology, Leeds Teaching Hospitals NHS Trust, St James's University Hospital, Leeds, UK \\ ${ }^{3}$ Neonatal Unit, Leeds Teaching Hospitals NHS Trust, Leeds, UK
}

Correspondence to Dr Rana Alia, ranaalia@msn.com

\section{DESCRIPTION}

A full-term baby girl weighing $2.9 \mathrm{~kg}$ was born by normal delivery. The anomaly scan at 20 weeks (including a $3 \mathrm{D}$ facial scan) was normal. She was born in good condition, but was noticed to have bilateral purple-coloured tense mobile, non-pulsatile masses below the medial canthus (figure 1).

At $6 \mathrm{~h}$ of age, she had a cyanotic episode with airway obstruction soon after feeding. She underwent resuscitation, during which a naso-gastric tube was passed through each nostril, excluding choanal atresia. An ultrasound scan confirmed bilateral cystic enlargement of the lacrimal ducts $(14 \mathrm{~mm})$, with some debris present. A diagnosis of bilateral congenital dacryocystocele was made.

Probing both cysts under local anaesthetic through the lacrimal punctums resulted in the release of mucoid material with marked reduction in size. Breast feeding was established and the baby was discharged home with ophthalmology follow-up.

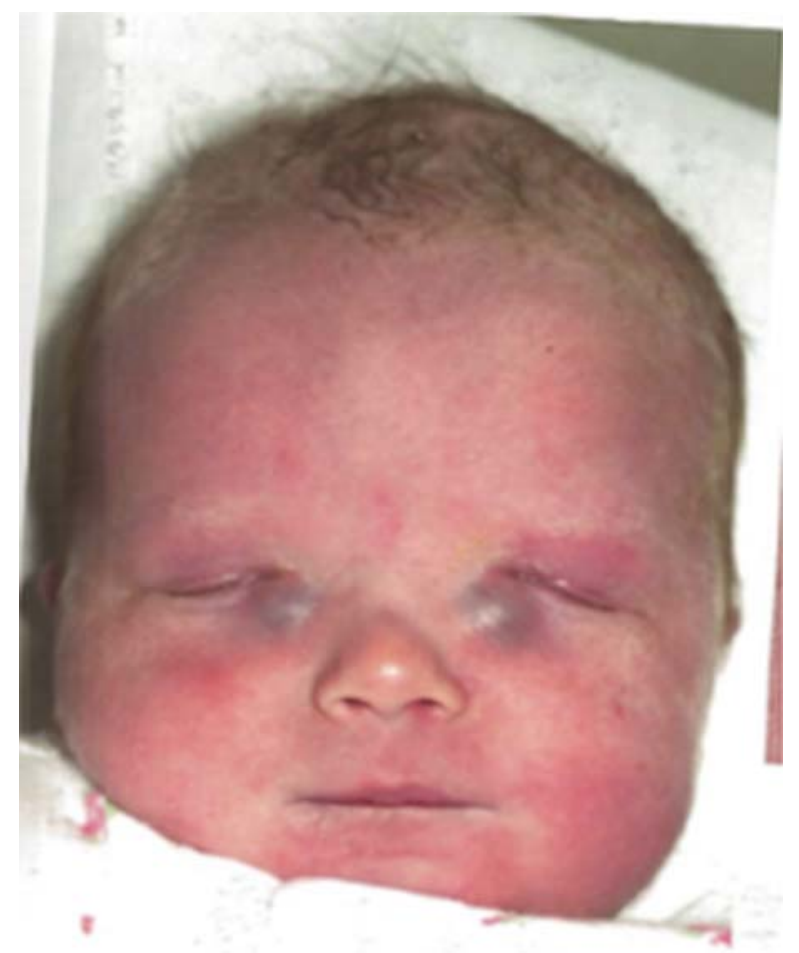

Dacryocystoceles account for only $0.1 \%$ of congenital nasolacrimal duct obstruction and classically presents shortly after birth, more common in girls and usually unilateral. ${ }^{1}$ Differential diagnoses include encephalocele, haemangioma, dermoid cyst and nasal gliomas. ${ }^{1}$ Ultrasound provides a non-invasive diagnosis. ${ }^{2}$ Complications include infection that can be treated with topical antibiotics, warm compresses and gentle massage. ${ }^{1}$ Serious complications include sepsis, cellulitis and upper airway obstruction. Urgent probing can reduce dacryocystitis and cellulitis, spontaneous resolution is described. ${ }^{1,3}$

\section{Learning points}

- Dacryocystocele is a rare, but important, cause of upper airway obstruction in neonates.

- Urgent referral to paediatric ophthalmology can prevent serious complications.

\section{Competing interests None}

Patient consent Obtained.

\section{REFERENCES}

1. Wong RK, Deborah K, Veen V. Presentation and management of congenital dacryocystocele. Pediatrics 2008;122;e1108-12.

2. Cavazza S, Laffi GL, Lodi L, et al. Congenital dacryocystocele: diagnosis and treatment. Acta Otorhinolaryngol Ital 2008;28:298-301.

3. Becker BB. The treatment of congenital dacryocystocele. Am J Ophthalmol 2006;142:835-8

Figure 1 Bilateral masses below medial canthus. 


\section{BMJ Case Reports}

This pdf has been created automatically from the final edited text and images.

Copyright 2012 BMJ Publishing Group. All rights reserved. For permission to reuse any of this content visit http://group.bmj.com/group/rights-licensing/permissions.

BMJ Case Report Fellows may re-use this article for personal use and teaching without any further permission.

Please cite this article as follows (you will need to access the article online to obtain the date of publication).

Alia R, Jeeva I, Miall L, Long V. A rare cause of upper airway obstruction in neonates. BMJ Case Reports 2012;10.1136/bcr-2012-006323, Published XXX

Become a Fellow of BMJ Case Reports today and you can:

- Submit as many cases as you like

- Enjoy fast sympathetic peer review and rapid publication of accepted articles

- Access all the published articles

- Re-use any of the published material for personal use and teaching without further permission

For information on Institutional Fellowships contact consortiasales@bmjgroup.com

Visit casereports.bmj.com for more articles like this and to become a Fellow 